\title{
Sensing Cd(II) Using a Disposable Optical Sensor Based on a Schiff Base Immobilisation on a Polymer-Inclusion Membrane. Applications in Water and Art Paint Samples
}

\author{
Lorena Sánchez-Ponce, María Dolores Galindo-Riaño (D), María José Casanueva-Marenco, \\ María Dolores Granado-Castro *(D) and Margarita Díaz-de-Alba (D)
}

Citation: Sánchez-Ponce, L.;

Galindo-Riaño, M.D.;

Casanueva-Marenco, M.J.;

Granado-Castro, M.D.; Díaz-de-Alba,

M. Sensing Cd(II) Using a Disposable

Optical Sensor Based on a Schiff Base

Immobilisation on a Polymer-Inclusion Membrane. Applications in Water and Art Paint Samples. Polymers 2021, 13, 4414. https://doi.org/10.3390/ polym 13244414

Academic Editor: Dalius Jucius

Received: 8 November 2021

Accepted: 10 December 2021

Published: 16 December 2021

Publisher's Note: MDPI stays neutra with regard to jurisdictional claims in published maps and institutional affiliations.

Copyright: (c) 2021 by the authors. Licensee MDPI, Basel, Switzerland. This article is an open access article distributed under the terms and conditions of the Creative Commons Attribution (CC BY) license (https:// creativecommons.org/licenses/by/ $4.0 /)$
Department of Analytical Chemistry, Institute of Biomolecules (INBIO), Faculty of Sciences, CEI-MAR, Campus Río San Pedro, University of Cádiz, ES-11510 Puerto Real, Spain; lorena.sanchezponce@alum.uca.es (L.S.-P.); dolores.galindo@uca.es (M.D.G.-R.); mariajose.casanueva@uca.es (M.J.C.-M.); margarita.diaz@uca.es (M.D.-d.-A.)

* Correspondence: dolores.granado@uca.es; Tel.: +34-956016455
Abstract: A disposable colour-changeable optical sensor based on an interesting polymer inclusionmembrane (PIM) was designed to determine $\mathrm{Cd}$ (II) ions in aqueous medium. The Schiff base 2-acetylpyridine benzoylhydrazone (2-APBH) immobilised on the polymer membrane was used as a sensing molecule. The amounts of the PIM components were optimised by a $3^{2}$ fractional factorial design with two central points and two blocks. The best optical sensor composition consisted of $2.5 \mathrm{~g}$ of poly(vinylchloride) (PVC) as a base polymer, $3 \mathrm{~mL}$ of tributyl phosphate (TBP) as a plasticiser, and $0.02 \mathrm{~g}$ of $2-\mathrm{APBH}$ as a reagent. The sensor showed a good linear response in the range from $0.02 \mathrm{mg} \mathrm{L}^{-1}$ (limit of detection) to $1 \mathrm{mg} \mathrm{L}^{-1}$ of $\mathrm{Cd}(\mathrm{II})$ under the following experimental conditions: pH 9.5 (adjusted using ammonium chloride buffer solution at $0.337 \mathrm{~mol} \mathrm{~L}^{-1}$ ), $60 \mathrm{~min}$ of exposure time plus $2 \mathrm{~min}$ of sonication (pulses at $2 \mathrm{~s}$ intervals), and $10 \mathrm{~min}$ of short-term stability. The relative standard deviation of the method was determined to be $4.04 \%$ for $0.4 \mathrm{mg} \mathrm{L}^{-1}$ of Cd(II). The optical sensor was successfully applied to the determination of $\mathrm{Cd}(\mathrm{II})$ in natural-water and art-paint samples.

Keywords: polymer-inclusion membrane; $\mathrm{Cd}(\mathrm{II})$ ions determination; optical sensor; PVC matrix; 2-acetylpyridine benzoylhydrazone

\section{Introduction}

A chemical sensor is a device that responds to a particular analyte in a selective way through a chemical reaction and can be used for its qualitative or quantitative determination. According to the traducer type, they can be categorised into: electrochemical, optical, mass sensitive, and heat sensitive [1]. Optical chemical sensors (often referred to as optodes) are a low-cost alternative to conventional methods, with high sensitivity and selectivity, fast response, and simple instrumentation. The response can be based on the absorption, emission, reflectance, photoluminescence, or chemiluminescence associated with the chemical interaction [1-5]. Membranes play a very important role in chemical sensing. The application of polymer-inclusion membranes (PIMs) as sensing components in ion-selective electrodes (IEs) and optodes [6-8] has generated great interest. PIMs have also been used for separation $[9,10]$, preconcentration [11], and passive sampling [12,13], resulting in a functional, cheaper, and more environmentally friendly alternative methodology [14].

PIMs essentially consist of three components: a base polymer, a reagent (to facilitate the binding with the species of interest), and a plasticiser. They are generally prepared by the solution casting method, where these components are dissolved in an organic volatile solvent, such as tetrahydrofuran (THF), 2-metiltetrahydrofuran (MeTHF), or dichloromethane (DMC). The solvent is finally evaporated, and a thin polymeric film is formed [15]. The base polymer gives stability to the membrane, where poly(vinyl chloride) (PVC) and 
cellulose triacetate (CTA) are some of the most used. The reagent immobilised into the PIM allows the membrane-analyte interaction and the plasticiser confers flexibility to the membrane $[6,16,17]$. Other possible components are additives, such as anion or cation exchangers (trioctylmethylammonium chloride (Aliquat 336), dinonylnaphthalene sulphonic acid (DNNS), etc.), which may improve the selective extraction of the analyte [18-20]. Depending on the base polymer, reagent, plasticiser, modifier, and additive used in the synthesis, PIMs can show different physicochemical properties.

PIMs have been used as optical chemical sensors for the selective separation and determination of metal ions by spectrophotometry (for example, $\mathrm{Zn}$ (II) determination in water, food supplements, and foot healthcare products [21]; $\mathrm{Al}$ (III) in aqueous samples [16]; or $\mathrm{Cd}(\mathrm{II}), \mathrm{Zn}(\mathrm{II})$, and $\mathrm{Cu}(\mathrm{II})$ in real water samples [22]), spectrofluorometry (such as $\mathrm{Fe}(\mathrm{III})$ in real samples [23] and $\mathrm{Al}(\mathrm{III})$ in natural water [24,25]), or colour-intensity measurements (such as $\mathrm{Cu}$ (II) [26] and $\mathrm{Ag}(\mathrm{I})$ and $\mathrm{Hg}(\mathrm{II})$ [27] in water samples), among others. In this sense, the use of Schiff bases in PIMs design can be very interesting since they are very effective chelating reagents used for the analysis, removal, and recovery of metal ions. Among them, hydrazones are characterised by the presence of the group $=\mathrm{C}=\mathrm{N}-\mathrm{N}=$, offering good optical properties after the complexation of metal ions such as $\mathrm{Ni}, \mathrm{Co}, \mathrm{Zn}, \mathrm{Cd}$, or $\mathrm{Cu}$ [28].

Some heavy metals may be very toxic at low concentrations, such as arsenic, cadmium, chromium, mercury, or lead, which are known as non-essential trace elements [29]. Cadmium is one of the heavy metals with major environmental risk [30]; moreover, it has been recognised as a human carcinogen by the World Health Organization. Usually, cadmium is a naturally occurring element present in all soils from both geogenic (as natural component of rocks) and anthropogenic sources ( $0.16 \mathrm{mg} \mathrm{kg}^{-1}$ in the Earth's crust [31]). Many anthropogenic processes, such as pigment, ceramic and battery production, and agriculture, among others, cause the increase in cadmium concentration in air, soil, and water [32]. This increase and the high persistence of its compounds in the environment produce a greater risk for living organisms exposed to cadmium [33,34]. In 2014, the European Union stated the tolerable cadmium intake per week in $2.5 \mathrm{\mu g} \mathrm{kg}^{-1}$ of body weight [35]. Cadmium intoxication may lead to renal tubular injury [36], hepatic, skeletal and cardiovascular damage, and even cancer [37]. Humans can be daily exposed to Cd via air, drinking water, or food. Different studies have described this exposure due to the intake of some infant formulas and baby foods [38], cereals [39], small bivalves and crustaceans [40], cigarettes smoke [41], handling of batteries [42], or the use of paints and articles coloured with pigments such as toys, ceramics, plastics, or decorated glassware [43].

There are some studies regarding the use of PIMs for selective extraction of cadmium ions [44-46], but very few studies are focused on its application as an optical sensor. Sanchez-Pedreño et al. [47] studied three kinetic methods using 1-(2-pyridylazo)-2-naphtol (PAN)-PVC-NPOE as a reagent for a Cd-based PIM sensor applied to Wood's alloy and water samples. These measurements were carried out by means of diffuse-reflectance spectroscopy. The same reagent was used for a PIM-based optical sensor for Cd detection in natural waters [48] and for the quantitatively determination of $\mathrm{Cd}(\mathrm{II}), \mathrm{Zn}(\mathrm{II})$, and $\mathrm{Cu}(\mathrm{II})$ in wastewater samples from a nonferrous metal smelter by UV-Vis spectrophotometry [22].

The aim of this study was the design of a polymer-inclusion membrane (PIM) as an optical sensor to determine $\mathrm{Cd}(\mathrm{II})$ ions using the Schiff base 2-acetylpyridine benzoylhydrazone as chemosensor (2-APBH; molecular formula: $\mathrm{C}_{14} \mathrm{H}_{13} \mathrm{~N}_{3} \mathrm{O}$; molecular weight: 239.3; $\left.\mathrm{mp}: 154-156^{\circ} \mathrm{C}\right)$. This reagent forms chromogenic complexes with different transition metal ions such as $\mathrm{Cd}(\mathrm{II}), \mathrm{Ni}(\mathrm{II}), \mathrm{Cu}(\mathrm{II}), \mathrm{Pb}(\mathrm{II}, \mathrm{Ti}(\mathrm{IV}), \mathrm{Fe}(\mathrm{III}), \mathrm{Fe}(\mathrm{II})$, etc. [49]. It is a biologically active aroylhydrazone with antibacterial and antifungal activities that has been used as antitubercular drug [50]. This ligand shows a maximum absorption at $300 \mathrm{~nm}$ in water solution with a bathochromic shift at alkaline conditions. The $\mathrm{pK}$ values in aqueous medium are found to be $3.6 \pm 0.3$ and $11.1 \pm 0.1$ at $0.1 \mathrm{~mol} \mathrm{~L}^{-1}$ ionic strength. The protonation of the pyridine $\mathrm{N}$ atom may be associated with the first $\mathrm{pK}$, and the deprotonation of $-\mathrm{NHCO}-$ group corresponds with the second $\mathrm{pK}$. This heterocyclic ligand exhibits two tautomeric structures (carbonyl-enol group) and can form coordination complexes through the oxygen 
atom of the enol form, the azomethine nitrogen, and/or the acetylpyridine ring nitrogen (Figure 1). Thus, it can act as a bidentate or tridentate ligand producing a five-membered ring [49].<smiles>C/C(=N\NC(=O)c1ccccc1)c1ccccn1</smiles>

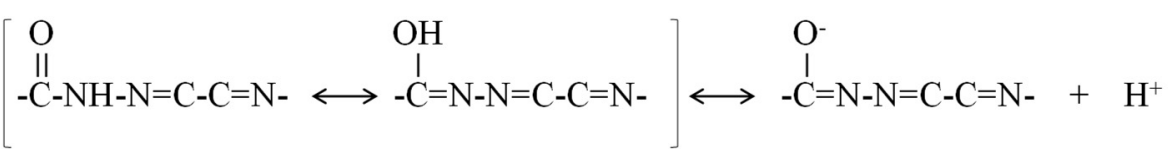

Figure 1. The chemosensor 2-acetylpyridine benzoylhydrazone (2-APBH) and its tautomeric structures [49].

The complexation reaction is highly influenced by the $\mathrm{pH}$ of the solution, and it is favoured at neutral or alkaline media in which the -NHCO- group can be deprotonated. The hydrolysis of the ligand can take place at low $\mathrm{pH}$ values, but it can be avoided using acetate or ammonia buffer solutions. The reagent 2-APBH and $\mathrm{Cd}(\mathrm{II})$ ion forms a stable yellow complex showing the maximum absorbance at $345 \mathrm{~nm}$ in neutral solution with a metal:ligand ratio stoichiometry of 1:2 [51]. Thus, this ligand presents interesting properties to be used as an optical chemosensor for Cd ions.

\section{Materials and Methods}

\subsection{Reagents and Solutions}

All reagents and solvents were of analytical-reagent or Suprapur grade, and all the solutions were prepared using ultra-high-quality water. Aqueous solutions of $\mathrm{Cd}$ (II) were prepared using a cadmium ICP standard solution of $1000 \mathrm{mg} \mathrm{L}^{-1}$ (Merk, Darmstadt, Germany) in $0.05 \mathrm{~mol} \mathrm{~L}^{-1} \mathrm{HNO}_{3}$ (Merk, Darmstadt, Germany). Ammonium-chloride buffer solutions ( $\left.3 \mathrm{~mol} \mathrm{~L}^{-1}, \mathrm{pH} 8-10\right)$ were prepared using ammonia solution $(25 \%)$ and hydrochloric acid (37\%) (Merk, Darmstadt, Germany). In order to increase the ionic strength of metal solutions, $\mathrm{NaNO}_{3}$ (analytical grade, D'Hemio Laboratorios, Carabanchel, Madrid Spain) and $\mathrm{NaClO}_{4}$ (prepared from $\mathrm{HClO}_{4}$ and $\mathrm{NaOH}$ (analytical grade, Panreac, Castellar del Vallès, Barcelona, Spain) were used. To digest the acrylic paint, $\mathrm{HNO}_{3}(65 \%)$, $\mathrm{H}_{2} \mathrm{O}_{2}(30 \%)$, and $\mathrm{HClO}_{4}(70 \%)$ (Suprapur grade, Merk, Darmstadt, Germany) were used.

For the synthesis of the PIM, poly(vinyl chloride) (PVC) (Sigma-Aldrich, St. Louis, MO, USA) as a base polymer, tributyl phosphate (TBP) (Sigma-Aldrich, St. Louis, MO, USA) as a plasticiser, tetrahydrofuran (THF) (Panreac, Castellar del Vallès, Barcelona, Spain) as a volatile solvent, and 2-acetylpyridine benzoylhydrazone (2-APBH) as the chromogenic reagent were used. The Schiff base (2-APBH) was synthesised by reaction of $2-$ acetylpyridine (Sigma-Aldrich, St. Louis, MO, USA) and benzoylhydrazine (Sigma-Aldrich, St. Louis, MO, USA) [50].

Interferences were studied by using stock aqueous solutions of $\mathrm{Ag}(\mathrm{I}), \mathrm{Al}(\mathrm{III}), \mathrm{As}(\mathrm{V})$, $\mathrm{Bi}(\mathrm{III}), \mathrm{Cr}$ (III), $\mathrm{Cu}(\mathrm{II}), \mathrm{Fe}(\mathrm{II}), \mathrm{Fe}(\mathrm{III}), \mathrm{K}(\mathrm{I}), \mathrm{Ni}(\mathrm{II}), \mathrm{Pb}(\mathrm{II}), \mathrm{Se}(\mathrm{II}), \mathrm{Ti}(\mathrm{IV}), \mathrm{Tl}(\mathrm{I}), \mathrm{V}(\mathrm{IV})$, and V(V). These solutions were prepared from an ICP standard solution of $1000 \mathrm{mg} \mathrm{L}^{-1}$ in $0.05 \mathrm{mg} \mathrm{L}^{-1}$ $\mathrm{HNO}_{3}$ (Certipur, Merk, Darmstadt, Germany). Fe(II) was prepared from Fe(III) solution in the presence of ascorbic acid (4.75 $\mathrm{mg} \mathrm{L}^{-1}$ ascorbic acid: $1 \mathrm{mg} \mathrm{L}^{-1} \mathrm{Fe}(\mathrm{III})$ ratio).

\subsection{Instrumentation}

Ultrapurified water was obtained by reverse osmosis with an Autwomatic (Water type II) system followed by ion exchange with an $18.2 \mathrm{M} \Omega \mathrm{cm}$ deionised Ultramatic Plus system (Wasserlab, Barbatáin, Navarra, Spain). Reagents and aqueous solutions were prepared under an 870-FL vertical laminar flow cabinet (Cruma, Saint Boi de Llobregat, 
Barcelona, Spain). The $\mathrm{pH}$ measurements were conducted using a Basic $20 \mathrm{pH}-\mathrm{meter}$ with a 50_10T glass-Ag/ $\mathrm{AgCl}$ electrode (Crison, Barcelona, Spain). The samples were shaken by means of an HS 501 D shaker platform (Ika, Labortechnik, Staufen, Germany). The polymer-inclusion membranes were synthesised inside a fume hood (Flowtronic, Romero S.A., Torrejón de Ardoz, Madrid, Spain), and an ultrasonic bath (Ultrasons, 9L, J.P. Selecta, Lardero, La Rioja, Spain) was used in order to homogenise and dissolve the PIM components. A Q700 high-energy ultrasound generator (Qsonica Sonicators, Newtown, CT, USA) was used for the sonication of the metal solutions in contact with the PIM. A handmade polyester film support (thickness: $25 \mu \mathrm{m}$, Mylar ${ }^{\circledR}$, Dupont, Hopewell, VA, USA) was used for the UV-Vis measurements of the PIM due to its special optical characteristics. The absorbance values were measured with a high-quality V-650 double beam UV-Vis spectrophotometer (Jasco, Hachioji, Tokio, Japan) controlled by Spectra ManagerTM software (Jasco, Hachioji, Tokio, Japan). Real samples were digested in vessels (Teflon autoclaves) under a controlled temperature by an ETHOS 1 Advanced Microwave Digestion System (Milestone, Sorisole, Bergamo, Italy). In order to prove the accuracy and reliability of the method, real samples were analysed by both flame atomic absorption spectroscopy using a Thermo Scientific ICE 3000 Series AA Spectrometer (Thermo Fisher Scientific, Winsford, UK) and the proposed sensor.

\subsection{Membrane Preparation}

The potential use of the reagent 2-APBH as a sensing molecule immobilised in a polymeric membrane of PVC (base polymer) and TBP (plasticizer) was proposed in a previous work. These components provide a homogeneous, flexible, mechanically strong, and optically transparent membrane [21]. In this study, the amounts of PIM components for $\mathrm{Cd}$ determination were optimised by applying a $3^{(\mathrm{k}-1)}$ factorial design with two repetitions of the central point in two blocks. This chemometric tool allows evaluating the effects of the experimental factors and their interactions on the response of the optical sensor. For that, the amounts of components for each experiment of the design were dissolved in $19.1 \mathrm{~mL}$ of THF (volatile solvent) by means of an ultrasonic bath until a homogeneous solution was obtained. The mixture was then deposited on a glass Petri dish of $11.7 \mathrm{~cm}$ diameter, which was covered with a piece of filter paper to allow THF to evaporate into a dark fume hood for a curing time of $24 \mathrm{~h}$ at a controlled room temperature of $20^{\circ} \mathrm{C}$. After that, the membrane obtained was cut into rectangular portions $(2.37 \mathrm{~cm} \times 0.98 \mathrm{~cm}$ size $)$ and assembled onto a piece of polyester film $(4.75 \mathrm{~cm} \times 0.98 \mathrm{~cm}$ size $)$. This ensemble was used as an optical sensor (optode) and was stored into a desiccator in the absence of light until its use. The absorbance data from the $\mathrm{Cd}$ sensing experiments were obtained using Spectra Manager ${ }^{\mathrm{TM}}$ software (Jasco, Hachioji, Tokio, Japan) and then exported to Microsoft Excel 2016 (Microsoft Corporation, Redmond, WA, USA) for data processing. The results of the experimental design were analysed using the software Statgraphics Centurion XVII (Statpoint Technologies, Inc., The Plains, VA, USA).

\subsection{Analytical Procedure for Optical Sensing of Cd(II) Ions}

The batch experiments were based on letting the optical sensor equilibrates with the $\mathrm{Cd}$ (II) sample solution and the subsequent measurement of the absorbance of the complex formed between $\mathrm{Cd}(\mathrm{II})$ and the Schiff base (2-APBH) by UV-Vis spectrophotometry. For each experiment, the optical sensor was immersed into $20 \mathrm{~mL}$ of Cd(II) solution (or blank solution) at $\mathrm{pH} 9$ (buffered by $0.225 \mathrm{~mol} \mathrm{~L}^{-1}$ of ammonium chloride/ammonia solution) using $100 \mathrm{~mL}$ polypropylene containers. The container was shaken at $300 \mathrm{rpm}$ for $60 \mathrm{~min}$ at $20^{\circ} \mathrm{C}$. Afterwards, the sensor was taken out of the container, rinsed with ultrapurified water, dried with absorbent paper, and stored for $10 \mathrm{~min}$ into a desiccator in the absence of light. The $\mathrm{pH}$ of the sample solution was controlled by measuring it before and after the exposure to the sensor. Finally, the optical sensor was perpendicularly placed into a quartz cuvette, and the absorbance was measured by a UV-Vis spectrophotometer at $379 \mathrm{~nm}$ (wavelength of maximum absorption of the Cd(II)-2-APBH complex). A piece 
of the polyester film was used as a reference measurement. The difference between the absorbance of the sensor after and before the experiment was defined as the sensor response. All experiments were carried out in duplicate.

\subsection{Real Samples Preparation}

In order to ensure the accuracy and reliability of the proposed method for the determination of $\mathrm{Cd}(\mathrm{II})$ ions, real samples were analysed by using the designed optical sensor under the optimal conditions. The results were compared to the ones obtained by AAS. The analytical procedures to prepare the real samples were as follows:

(a) Spiked groundwater Groundwater-certified reference material (BCR $\left.{ }^{\circledR}-610\right)$ (Joint Research Centre (JRC), Institute for Reference Materials and Measurements (IRMM), with a certified value for $\mathrm{Cd}$ of $2.94 \pm 0.08 \mu \mathrm{g} \mathrm{kg}{ }^{-1}$ ) was directly used for assessing the method performance.

(b) Art-paint samples Two school acrylic art-paint samples were analysed: "cadmium yellow orange" (P020 colour index) and "cadmium red deep" (PR108 colour index). For that, $0.1 \mathrm{~g}$ of each paint were digested using $1 \mathrm{~mL}$ of $\mathrm{HNO}_{3}(65 \%), 1 \mathrm{~mL}$ of $\mathrm{H}_{2} \mathrm{O}_{2}$ $(30 \%)$, and $1 \mathrm{~mL}$ of $\mathrm{HClO}_{4}(70 \%)$ in a Teflon vessel (waiting $24 \mathrm{~h}$ between the addition of each reagent $\left(\mathrm{HNO}_{3}, \mathrm{H}_{2} \mathrm{O}_{2}\right.$, and $\left.\mathrm{HClO}_{4}\right)$; vessels were kept closed during that time). Two steps were followed for the digestion of the sample in a microwave oven at these conditions: $800 \mathrm{~W}, 120^{\circ} \mathrm{C}$ for $10 \mathrm{~min}$ and $800 \mathrm{~W}, 170{ }^{\circ} \mathrm{C}$ for $30 \mathrm{~min}$. The solution was made up to $25 \mathrm{~mL}$ with ultrapurified water. The final solutions for both art paints were diluted to obtain four different samples called acrylic paint 1, 2, 3, and 4 , where 1 and 2 were two different dilutions from "yellow cadmium orange" paint and 3 and 4 were two different dilutions from "dark red cadmium" paint. These four samples were analysed following the new methodology proposed in this work for the determination of $\mathrm{Cd}(\mathrm{II})$ ions.

\section{Results}

\subsection{Optimisation of the Optical Sensor Composition and Curing Time}

In order to study the optimal composition of the optical sensor, a $3^{(\mathrm{k}-\mathrm{k})}$ fractional factorial design with two central points and two blocks was performed studying three variables (amount of PVC $(\mathrm{g})$, volume of TBP $(\mathrm{mL})$, and amount of 2-APBH $(\mathrm{g})$ ) by following the procedure described in Section 2.3. The exponent $\mathrm{k}$ indicates the number of variables, and the base indicates the levels of each variable. All variables presented three levels: an upper level (+1), a central level (0), and a lower level (-1). The corresponding values of each level for the different variables are shown in Table 1. A total of 22 random runs were performed: each membrane composition was prepared twice in different days, and, in turn, the exposure experiment for each membrane was carried out in duplicate. All the experiments were carried out by exposing the sensor to $1 \mathrm{mg} \mathrm{L}^{-1}$ of $\mathrm{Cd}(\mathrm{II})$ solutions at pH 9 (buffered by $0.225 \mathrm{mg} \mathrm{L}^{-1}$ ammonium chloride/ammonia solutions). The difference between the absorbance measurement of the sensor before and after the exposure time (30 $\mathrm{min}$ ) to the solution is defined as the response of the sensor. Table 2 shows the matrix of each experiment, the response of the sensor exposed to $\mathrm{Cd}(\mathrm{II})$, and the standard deviation of these measurements. The significance of the effects of the three variables was studied for a 95\% confidence interval. The analysis of the experimental design showed non-significant interactions between the effects of the sensor exposed to $\mathrm{Cd}(\mathrm{II})$ on the response. The Pareto chart for the lineal (L) and quadratic (Q) main effects is shown in Figure 2. 
Table 1. Values of each level for the three variables studied.

\begin{tabular}{cccc}
\hline Variable & \multicolumn{3}{c}{ Level } \\
\hline & Lower Level (-1) & Central Level (0) & Upper Level (+1) \\
\hline PVC $(\mathrm{g})$ & 2 & 2.5 & 3 \\
TBP $(\mathrm{mL})$ & 3 & 4 & 5 \\
2-APBH $(\mathrm{g})$ & 0.02 & 0.03 & 0.04 \\
\hline
\end{tabular}

Table 2. Matrix of the $3^{3-1}$ experimental design $(22$ runs; $n=2)$ and response of the optical sensor exposed to $1 \mathrm{mg} \mathrm{L}^{-1}$ of $\mathrm{Cd}(\mathrm{II})$ at $\mathrm{pH} 9(\mathrm{n}=2)$.

\begin{tabular}{ccccccc}
\hline $\begin{array}{c}\text { Replicates of } \\
\text { Composition }\end{array}$ & Experiment & PVC $(\mathbf{g})$ & TBP $(\mathbf{m L})$ & 2-APBH $(\mathbf{g})$ & \multicolumn{2}{c}{ Abs (379 $\mathbf{~ m})$} \\
\hline 1 & 1 & -1 & -1 & -1 & Mean & SD \\
\hline 1 & 2 & -1 & 0 & 1 & 1.682 & 0.119 \\
1 & 3 & -1 & 1 & 0 & 1.536 & 0.005 \\
1 & 4 & 0 & -1 & 1 & 1.880 & 0.044 \\
1 & 5 & 0 & 0 & 0 & 1.695 & 0.059 \\
1 & 6 & 0 & 1 & -1 & 1.691 & 0.011 \\
1 & 7 & 1 & -1 & 0 & 2.117 & 0.008 \\
1 & 8 & 1 & 0 & -1 & 1.712 & 0.009 \\
1 & 9 & 1 & 1 & 1 & 1.601 & 0.006 \\
1 & 10 & 0 & 0 & 0 & 1.826 & 0.421 \\
1 & 11 & 0 & 0 & 0 & 1.488 & 0.016 \\
2 & 12 & -1 & -1 & -1 & 1.892 & 0.142 \\
2 & 13 & -1 & 0 & 1 & 1.321 & 0.149 \\
2 & 14 & -1 & 1 & 0 & 1.694 & 0.128 \\
2 & 15 & 0 & -1 & 1 & 1.962 & 0.232 \\
2 & 16 & 0 & 0 & 0 & 2.036 & 0.159 \\
2 & 17 & 0 & 1 & -1 & 1.477 & 0.178 \\
2 & 18 & 1 & -1 & 0 & 1.846 & 0.172 \\
2 & 19 & 1 & 0 & -1 & 1.832 & 0.510 \\
2 & 20 & 1 & 1 & 1 & 1.591 & 0.200 \\
2 & 21 & 0 & 0 & 0 & 1.609 & 0.304 \\
2 & 22 & 0 & 0 & 0 & 1.697 & 0.050 \\
\hline
\end{tabular}

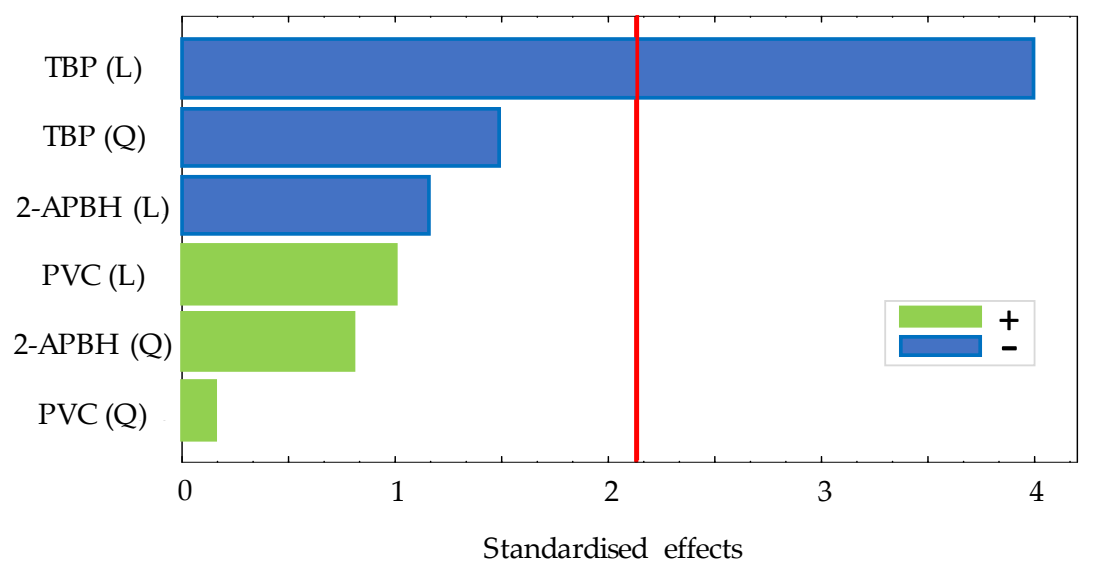

Figure 2. Pareto chart for $3^{(3-1)}$ experimental design for optical sensor response (red line: significance level of $5 \%$ ).

According to it, the volume of TBP showed a significant negative linear effect on the response, being the optimum factor level as (-1). The amount of PVC and 2-APBH showed a non-significant effect. The best PIM composition to be used for $\mathrm{Cd}(\mathrm{II})$ sensing combines the highest response of the sensor exposed to cadmium, the lower reagent consumption, and the lower standard deviation between replicates, although the two last effects were not 
significant. For that purpose, the synthesis and the curing time of the sensor from different runs ((PVC, TBP, 2-APBH): $-1,-1,-1 ; 0,-1,-1 ;-1,-1,0$; and $0,-1,0)$ with the reagent consumption as low as possible (level $(-1)$ and level (0)) was evaluated. Figure 3 shows the response of the sensor for different combinations of PVC and 2-APBH levels after exposure to $1 \mathrm{mg} \mathrm{L}^{-1}$ of $\mathrm{Cd}$ (II) solution at $\mathrm{pH} 9$ for $24,48,72$, and $96 \mathrm{~h}$ of curing time.

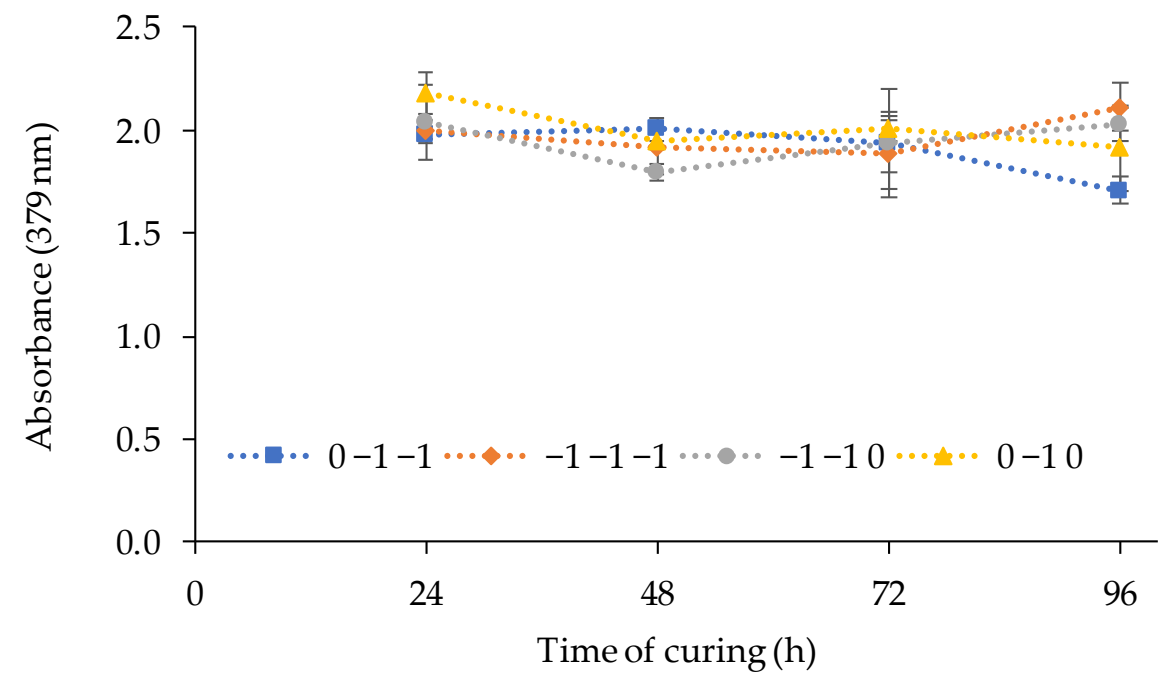

Figure 3. Effect of the curing time on the sensor response (exposed to $1 \mathrm{mg} \mathrm{L}^{-1}$ of $\mathrm{Cd}$ (II) solutions at $\mathrm{pH} 9$ ) for different combinations of PVC and 2-APBH levels.

The results showed in most cases a decrease in the sensor signal after the first 48 $h$ of curing. On the other hand, the best stability of the signal, and therefore the lower deviation between replicates for the first $48 \mathrm{~h}$, corresponded to the synthesis of the PIM with the central level of PVC (0) and the lower level of 2-APBH (-1). Thus, the optimal PIM composition to obtain the best response of the sensor was established in: $2.5 \mathrm{~g}$ of $\mathrm{PVC}, 3 \mathrm{~mL}$ of TBP, and $0.02 \mathrm{~g}$ of 2-APBH. In addition, the curing of the optical sensor can be completed within the first $24-48 \mathrm{~h}$ after the synthesis because, for $72 \mathrm{~h}$, a decrease was observed.

\subsection{Lifetime of the Optical Sensor}

The lifetime of the $\mathrm{Cd}(\mathrm{II})$ optical sensor is a fundamental aspect for the experimentation because it provides information about how many days the sensor can be used after the synthesis. A PIM (2.5 g PVC; $3 \mathrm{~mL}$ TBP; $0.02 \mathrm{~g} 2$-APBH) was synthesised following the procedure described in Section 2.3 in order to determinate its lifetime. The absorbance of the optical sensor due to the Schiff base (maximum absorption at $324 \mathrm{~nm}$ ) was measured at $6,12,24,30,48,96$, and $168 \mathrm{~h}$ after synthesis. The results for two replicates showed constant values of the absorbance up to $168 \mathrm{~h}$ (see Appendix A: Table A1). A $t$-test at a 95\% confidence interval was performed with the data obtained at 6 and $168 \mathrm{~h}$, indicating there were not significant differences between them. Therefore, this study proved that the sensor could be used up to seven days after synthesis.

\subsection{Effect of $p H$, Buffer Concentration, and Ionic Strength on the Response of the Sensor}

The $\mathrm{pH}$ value and the buffer concentration in the metal solution could affect the response of the sensor. Thus, the sensor was exposed to solutions of $1 \mathrm{mg} \mathrm{L}^{-1}$ of Cd(II) at different $\mathrm{pH}$ values $(8,8.5,9,9.5$, and 10$)$ controlled by $0.225 \mathrm{~mol} \mathrm{~L}^{-1}$ ammonia buffer solutions. The best responses of the sensor were obtained at $\mathrm{pH}$ 9-9.5 (Figure 4). The influence of the buffer concentration was also studied at $\mathrm{pH} 9.5$, obtaining a higher absorbance value for a buffer concentration of $0.337 \mathrm{~mol} \mathrm{~L}^{-1}$ (Figure 5). 


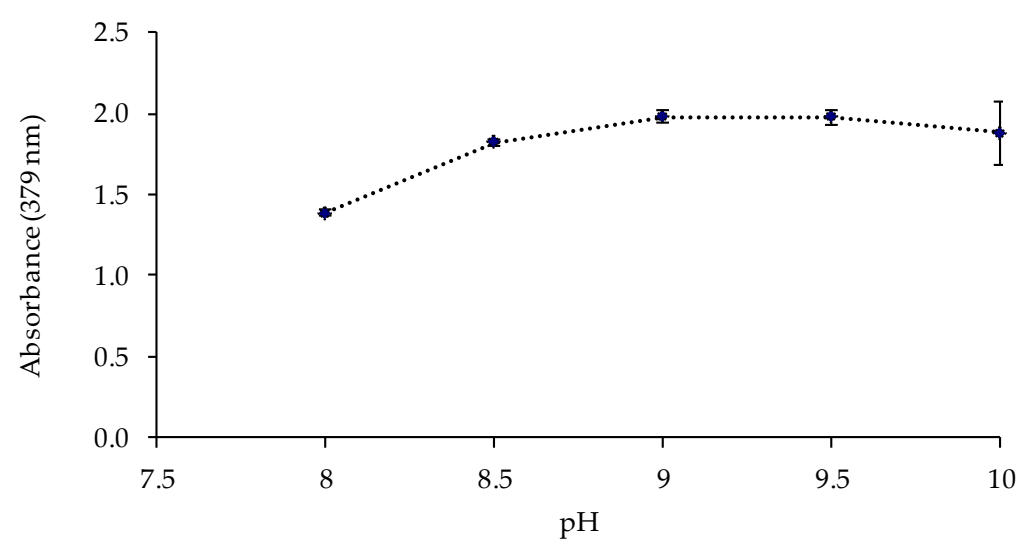

Figure 4. Effect of the $\mathrm{pH}$ value of the ammonium chloride/ammonia buffer solution on the sensor response ( $1 \mathrm{mg} \mathrm{L}^{-1} \mathrm{Cd}(\mathrm{II}) ; 0.225 \mathrm{~mol} \mathrm{~L}^{-1}$ buffer; $\mathrm{n}=2$ ).

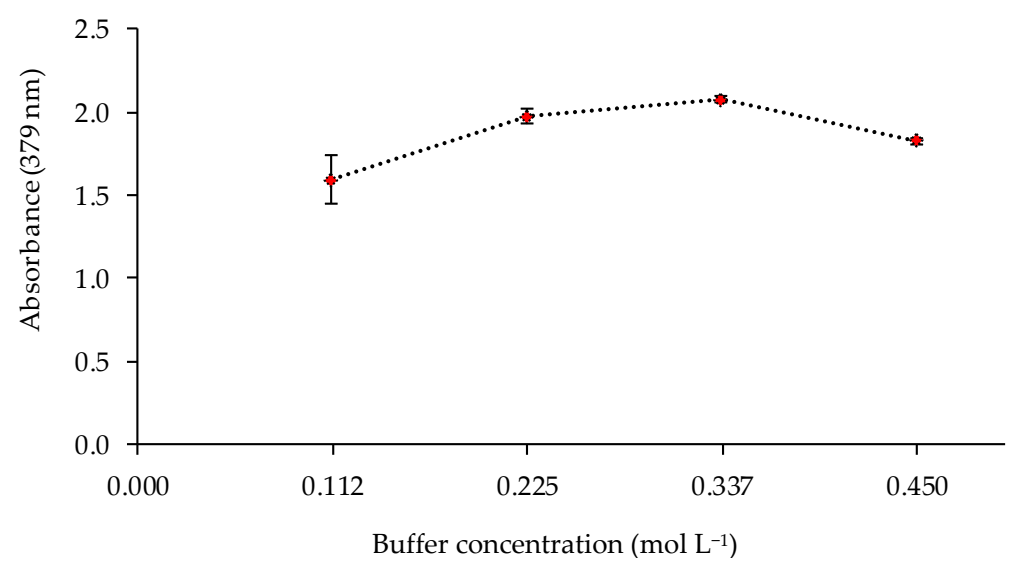

Figure 5. Effect of the buffer concentration on the sensor response $\left(1 \mathrm{mg} \mathrm{L}^{-1} \mathrm{Cd}(\mathrm{II}) ; \mathrm{pH} 9.5 ; \mathrm{n}=2\right)$.

The effect of the ionic strength of the metal solution on the response of the sensor was investigated. Two different salts $\left(\mathrm{NaNO}_{3}\right.$ and $\left.\mathrm{NaClO}_{4}\right)$ were used to increase the ionic strength of the solution by adding the following concentrations: $0,0.1,0.2$, and $0.3 \mathrm{~mol} \mathrm{~L}^{-1}$. As shown in Figure 6, the increase in ionic strength did not improve the sensor response.

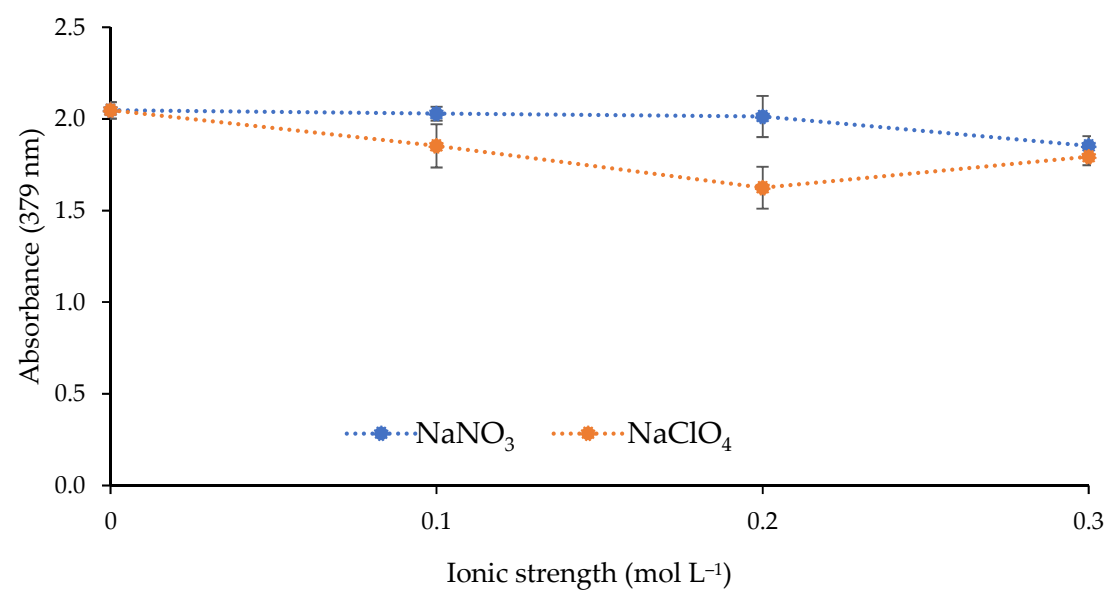

Figure 6. Effect of the ionic strength on the sensor response $\left(1 \mathrm{mg} \mathrm{L}^{-1} \mathrm{Cd}(\mathrm{II}) ; \mathrm{pH} 9.5 ; 0.337 \mathrm{~mol} \mathrm{~L}^{-1}\right.$ buffer; $\mathrm{n}=2$ ).

\subsection{Response Time of the Optical Sensor}

The response time of the optical sensor was studied to determinate the adequate time of exposure to the metal solution required to obtain a maximum and stable signal. For 
that purpose, the optical sensor was exposed to solutions of 1 and $0.1 \mathrm{mg} \mathrm{L}^{-1}$ of $\mathrm{Cd}(\mathrm{II})$ under the optimal conditions during different times $(5,30,60,90,120$, and $180 \mathrm{~min})$ by shaking at $300 \mathrm{rpm}$. According to the results (Figure 7), the exposure time to obtain the maximum response was $90 \mathrm{~min}$. After that, the response (absorbance value) remained constant. A sonication process of the optical sensor in the solution with a power of $21 \mathrm{~W}$ on a discontinuous mode ( $2 \mathrm{~min}$ of sonication pulses at $2 \mathrm{~s}$ intervals) was applied after shaking to promote the complexation of the metal by the PIM. As can be seen in Figure 7, a rise in the response time was observed since the sonication time reduced the metal exposure in $30 \mathrm{~min}$.

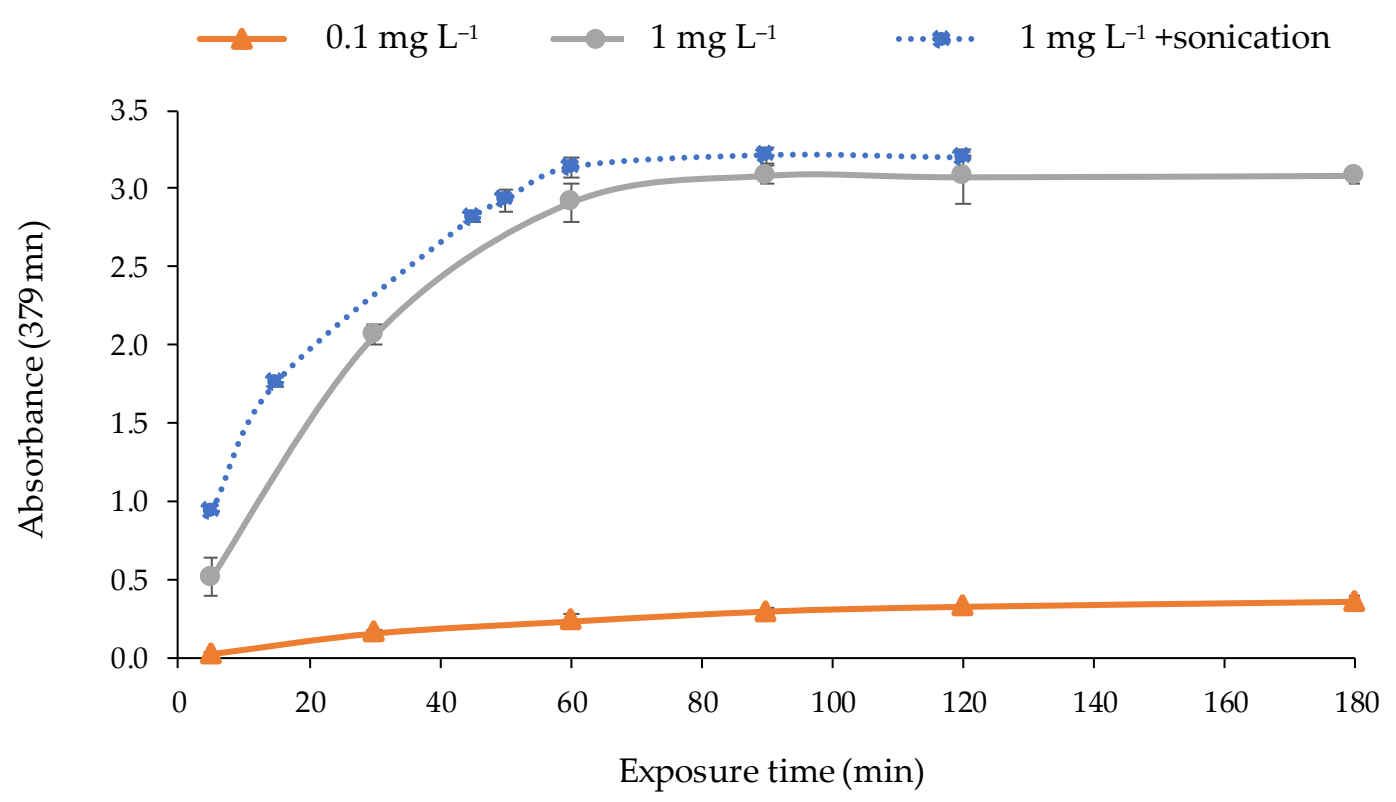

Figure 7. Response time of the optical sensor for different concentrations of $\mathrm{Cd}(\mathrm{II})\left(\mathrm{pH} 9.5 ; 0.337 \mathrm{~mol} \mathrm{~L}^{-1} \mathrm{buffer}\right.$; $=2$ ) exposed to: shaking $(-)$; shaking + sonication $(2 \mathrm{~min})(\cdots \cdots)$.

No longer sonication times were studied because the temperature of the solution was increased in excess, and the reagent is not thermally stable. The hydrolysis of 2-APBH occurs when temperature exceeds $35-40{ }^{\circ} \mathrm{C}[49,51]$. Therefore, the selected exposure time to the metal solution was $60 \mathrm{~min}$ followed by sonication for $2 \mathrm{~min}$ on a discontinuous mode.

\subsection{Short-Term Stability}

Short-term stability is the period of time that can elapse between the end of the exposure of the sensor to the metal solution and the absorbance measurement in the spectrophotometer without changes in the sensor response. This study was performed by exposing the sensor to $1 \mathrm{mg} \mathrm{L}^{-1} \mathrm{Cd}$ (II) at optimal conditions (PIM composition: $2.5 \mathrm{~g}$ PVC, $3 \mathrm{~mL}$ TBP, and $0.02 \mathrm{~g}$ 2-APBH; conditions of the metal solution: $\mathrm{pH} 9.5$ and $0.337 \mathrm{~mol} \mathrm{~L}^{-1}$ buffer solution concentration; $60 \mathrm{~min}$ of exposure time followed by $2 \mathrm{~min}$ of sonication). The absorbance was measured during $5 \mathrm{~h}$ after sonication. The results (Appendix A: Figure A1) showed a slight decrease over time after the first $15 \mathrm{~min}$ and a constant signal in the range of 30-120 min with a slight decrease again. Therefore, a 10 min short-term stability was selected as the waiting time before spectrophotometric measurement was performed, but any time within the interval from 30 to 120 min would also be applicable.

\subsection{Analytical Performance of the Method}

The analytical features of the method such as the limit of quantification (LQ) and detection (LD), the dynamic linear range, the precision, and the selectivity were determined. For that, the response of the sensor was obtained following the procedure previously described in Section 2.4 under optimal conditions. The LD was evaluated using $3 \sigma / \mathrm{m}$ 
( $n=10)$, where $\sigma$ is the standard deviation of the blank signal, and $m$ is the slope of the linear calibration plot. The calculated LD was $0.021 \mathrm{mg} \mathrm{L}^{-1}$. The LQ (evaluated as $10 \sigma / \mathrm{m}(\mathrm{n}=10))$ was $0.069 \mathrm{mg} \mathrm{L}^{-1}$. The relationship between the signal and the Cd(II) concentration was found to be linear over the concentration range from 0.05 to $1 \mathrm{mg} \mathrm{L}^{-1}$ with an equation of (Equation (1)):

$$
\operatorname{Abs}(379 \mathrm{~nm})=(2.884 \pm 0.012)[\mathrm{Cd}(\mathrm{II})]\left(\mathrm{mg} \mathrm{L}^{-1}\right)+(0.046 \pm 0.006)
$$

obtaining a correlation coefficient of $R^{2}=0.9966(n=10)$ and a standard error of estimate of 0.059 (Figure 8). The precision of the method, calculated from six replicate experiments using $0.4 \mathrm{mg} \mathrm{L}^{-1} \mathrm{Cd}(\mathrm{II})$ solutions at a confidence interval of $95 \%$, was $3.38 \%$, while the relative standard deviation was found to be $4.04 \%$.

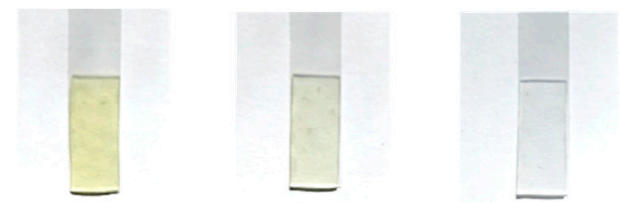

$0.8 \mathrm{mg} \mathrm{L}^{-1} \mathrm{Cd}(\mathrm{II}) \quad 0.4 \mathrm{mg} \mathrm{L}^{-1} \mathrm{Cd}(\mathrm{II}) \quad$ Blanck

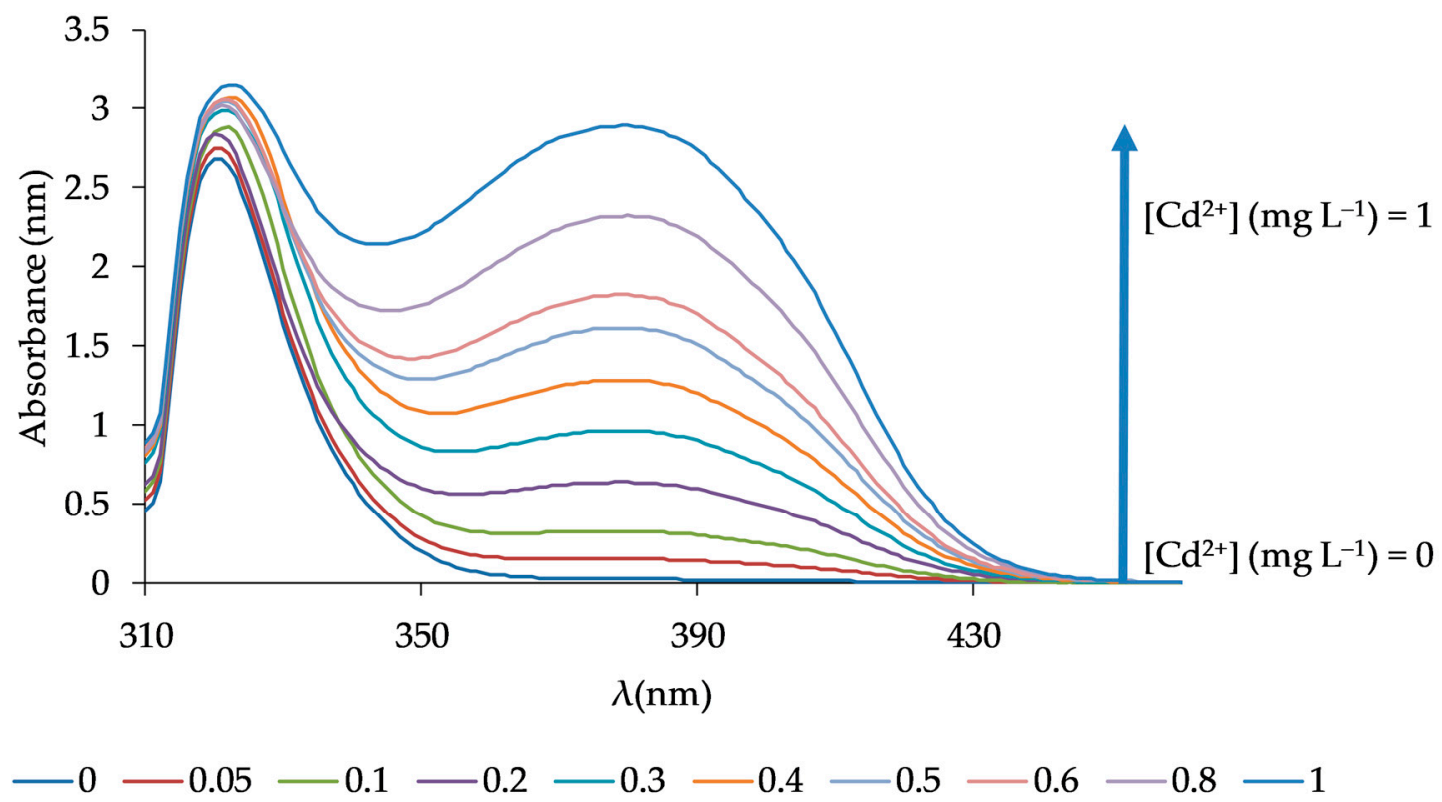

Figure 8. Response spectra of the optical sensor for different Cd(II) concentrations corresponding to the calibration curve.

The selectivity of the sensor was investigated as a function of the degree of interferences found in the presence of different ions such as $\mathrm{Ag}(\mathrm{I}), \mathrm{Al}(\mathrm{III}), \mathrm{As}(\mathrm{V}), \mathrm{Bi}(\mathrm{III}), \mathrm{Cr}$ (III), $\mathrm{Cu}(\mathrm{II}), \mathrm{Fe}(\mathrm{II}), \mathrm{Fe}(\mathrm{III}), \mathrm{K}(\mathrm{I}), \mathrm{Ni}(\mathrm{II}), \mathrm{Pb}(\mathrm{II}), \mathrm{Se}(\mathrm{II}), \mathrm{Ti}(\mathrm{IV}), \mathrm{Tl}(\mathrm{I}), \mathrm{V}(\mathrm{IV})$, and $\mathrm{V}(\mathrm{V})$. For that, the effects of these ions on the response of the sensor were evaluated at a 1:1 Cd(II): interfering ion ratio, using metal ion concentrations of $0.4 \mathrm{mg} \mathrm{L}^{-1}$. The tolerance limit was defined as the concentration of the added ion causing a relative error less than $\pm 5 \%$ in the optical-sensor response. The results are shown in Figure 9 and indicated that most of the studied ions produced low interference or did not affect the $\mathrm{Cd}$ response, except for $\mathrm{Cu}(\mathrm{II})$ and $\mathrm{Ni}(\mathrm{II})$ ions. The pre-treatment of the metal solution with dimethylglyoxime (DMG: $0.068 \mathrm{mmol} \mathrm{L}^{-1}$ ) addition and filtration before $\mathrm{Cd}(\mathrm{II})$ analysis avoided the $\mathrm{Ni}(\mathrm{II})$ interference (Figure 9). 


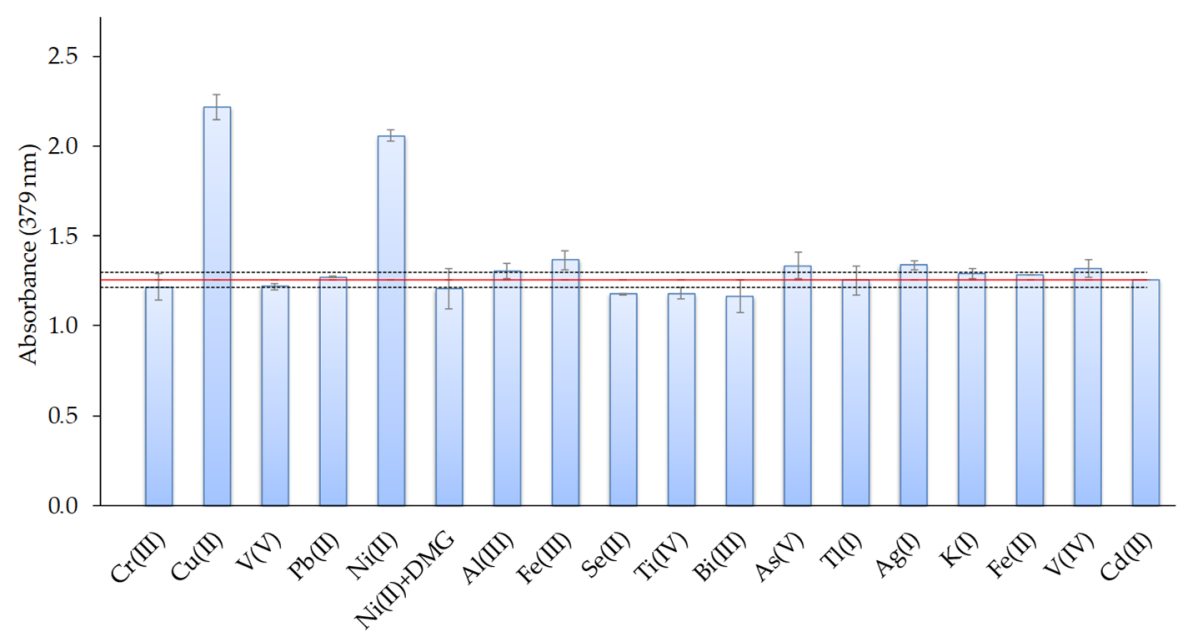

Figure 9. Effect of the presence of different metal ions on the response of the optical sensor for a 1:1 $\mathrm{Cd}(\mathrm{II})$ : interfering metal ratio (metal concentrations: $0.4 \mathrm{mg} \mathrm{L}^{-1} ; \mathrm{n}=2$ ).

\subsection{Analytical Applications}

In order to evaluate the accuracy of the method, spiked groundwater samples with different amounts of $\mathrm{Cd}(\mathrm{II})$ and acrylic art paint samples were analysed by using the proposed optical sensor. After that, the results were compared to those values obtained by AAS by means of a Student's t-test at a 95\% confidence interval. As shown in Table 3, there were no significant differences between both methods (optical sensor and AAS technique) in the quantitative determination of $\mathrm{Cd}(\mathrm{II})$. Therefore, the proposed optical sensor can provide reliable results and be used for the successful determination of $\mathrm{Cd}(\mathrm{II})$ ions in real samples such as waters and paints.

Table 3. Analysis of Cd(II) in real samples by the proposed optical sensor and AAS technique.

\begin{tabular}{|c|c|c|c|c|}
\hline \multirow{2}{*}{ Sample } & \multicolumn{2}{|c|}{$(\mathrm{Cd}(\mathrm{II})) \pm \mathrm{SD}\left(\mathrm{mg} \mathrm{L}^{-1}\right)$} & \multirow{2}{*}{$\mathbf{t}_{\text {calc }}$} & \multirow{2}{*}{$t_{\text {tab }}(95 \%)$} \\
\hline & Optical Sensor & AAS & & \\
\hline Spiked groundwater with $0.3 \mathrm{mg} \mathrm{L}^{-1}$ & $0.309 \pm 0.011$ & $0.300 \pm 0.002$ & 1.440 & 3.182 \\
\hline Spiked groundwater with $0.8 \mathrm{mg} \mathrm{L}^{-1}$ & $0.802 \pm 0.001$ & $0.806 \pm 0.002$ & 2.425 & 3.182 \\
\hline Acrylic paint 1 & $0.544 \pm 0.003$ & $0.538 \pm 0.009$ & 0.878 & 3.182 \\
\hline Acrylic paint 2 & $0.680 \pm 0.013$ & $0.664 \pm 0.002$ & 2.237 & 3.182 \\
\hline Acrylic paint 3 & $0.478 \pm 0.001$ & $0.485 \pm 0.004$ & 1.935 & 3.182 \\
\hline Acrylic paint 4 & $0.732 \pm 0.047$ & $0.743 \pm 0.001$ & 0.436 & 3.182 \\
\hline
\end{tabular}

\section{Conclusions}

A new optical sensor for Cd(II) determination was successfully developed and applied. The proposed sensor is based on the immobilisation of a Schiff base (2-APBH, a colorimetric chelating reagent) in a polymer-inclusion membrane (PIM). The sensor has been optimised and characterised by using spectrophotometric measurements. It offers good mechanical and optical properties, such a good reproducibility, precision, and selectivity with an easy and low-cost operation. The optical sensor showed good potential applicability and provided reliable results when analysing spiked groundwater and art-paint samples with different concentrations of $\mathrm{Cd}(\mathrm{II})$.

Author Contributions: Conceptualization: M.D.G.-R., M.D.-d.-A. and M.D.G.-C.; methodology: M.D.G.-R., L.S.-P. and M.D.G.-C.; software: M.D.G.-R., M.D.-d.-A. and M.D.G.-C.; validation: L.S.-P. and M.J.C.-M.; formal analysis: M.D.G.-R. and L.S.-P.; investigation: M.D.G.-R., L.S.-P. and M.D.G.-C.; resources: M.J.C.-M. and M.D.-d.-A.; data curation: L.S.-P., M.D.G.-R. and M.D.G.-C.; writingoriginal draft preparation: L.S.-P. and M.D.G.-R.; writing-review and editing: M.D.G.-R., M.D.-d.-A. and M.J.C.-M.; visualization: M.D.-d.-A. and M.J.C.-M.; supervision: M.D.G.-R.; funding acquisition: M.D.G.-R. All authors have read and agreed to the published version of the manuscript. 
Funding: This research was funded by "Consejería de Economía, Conocimiento, Empresas y Universidad," Junta de Andalucía (Spain) (support for RNM-236), and by the Programme of "Fomento e Impulso de la Investigación y de la Transferencia de la Universidad de Cádiz" (Spain) (PR2020-013).

Institutional Review Board Statement: Not applicable.

Informed Consent Statement: Not applicable.

Data Availability Statement: All data from this research are included in the article.

Acknowledgments: The authors would like to gratefully thank José Maria Palacios Santander for the ultrasound generator equipment.

Conflicts of Interest: The authors declare that they have no known competing financial interests or personal relationships that could have appeared to influence the work reported in this article.

\section{Appendix A}

Table A1. Lifetime of the optical sensor based on the absorbance measurements for several days after the synthesis of the PIM.

\begin{tabular}{|c|c|c|c|}
\hline Time (h) & Replicate & Absorbance (324 nm) & Absorbance Average \\
\hline \multirow{2}{*}{6} & 1 & 2.9883 & \multirow[b]{2}{*}{2.9789} \\
\hline & 2 & 2.9694 & \\
\hline \multirow{2}{*}{12} & 1 & 2.9872 & \multirow{2}{*}{2.9791} \\
\hline & 2 & 2.9709 & \\
\hline \multirow[b]{2}{*}{24} & 1 & 2.8851 & \multirow[b]{2}{*}{2.9310} \\
\hline & 2 & 2.9769 & \\
\hline \multirow{2}{*}{30} & 1 & 2.9916 & \multirow{2}{*}{2.9846} \\
\hline & 2 & 2.9775 & \\
\hline \multirow[b]{2}{*}{48} & 1 & 3.0012 & \multirow{2}{*}{2.9579} \\
\hline & 2 & 2.9146 & \\
\hline \multirow{2}{*}{96} & 1 & 2.9864 & \multirow{2}{*}{2.9937} \\
\hline & 2 & 3.0009 & \\
\hline \multirow{2}{*}{168} & 1 & 3.0087 & \multirow{2}{*}{3.0105} \\
\hline & 2 & 3.0123 & \\
\hline
\end{tabular}

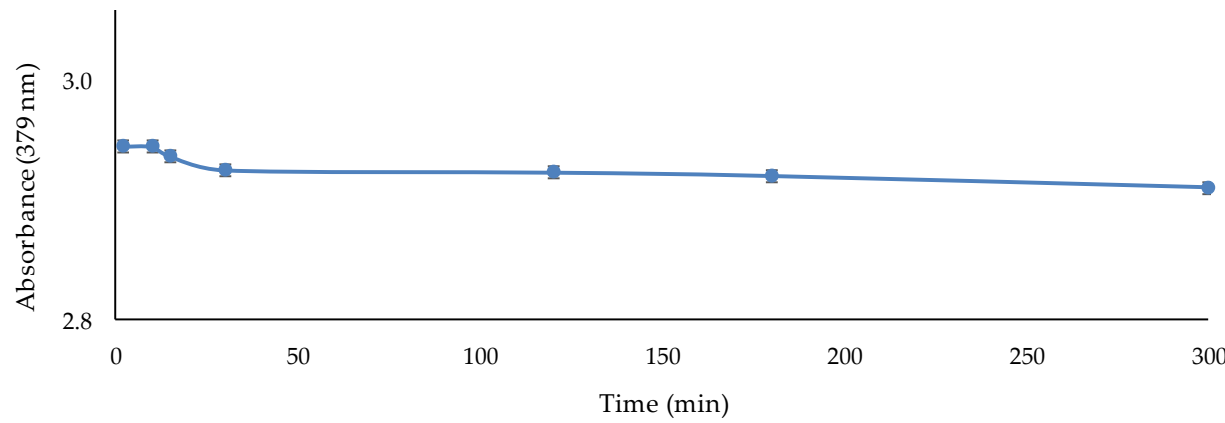

Figure A1. Study of the short-term stability of the optical sensor exposed to $1 \mathrm{mg} \mathrm{L}^{-1} \mathrm{Cd}(\mathrm{II})$.

\section{References}

1. Ojeda, C.B.; Rojas, F.S. Recent development in optical chemical sensors coupling with flow infection analysis. Sensors 2006, 6, 1245-1307. [CrossRef]

2. Zhu, H.; Zhou, X.; Su, F.; Tian, Y.; Ashili, S.; Holl, M.R.; Meldrum, D.R. Micro-patterning and characterization of PHEMA-coPAM-based optical chemical sensors for lab-on-a-chip applications. Sens. Actuators B-Chem. 2012, 173, 817-823. [CrossRef]

3. Ullah, N.; Mansha, M.; Khan, I.; Qurashi, A. Nanomaterial-based optical chemical sensors for the detection of heavy metals in water: Recent advances and challenges. Trends Anal. Chem. 2018, 100, 155-166. [CrossRef]

4. Dashtian, K.; Zare-Dorabei, R. Preparation and characterization of a novel optical chemical sensor for determination of trace amounts of Praseodymium ion by UV/Vis spectrophotometry. Sens. Actuators B-Chem. 2017, 242, 586-594. [CrossRef] 
5. Pan, Z.; Feng, J.; Hu, X.; Jia, C.; Huang, X. High sensitivity fiber sensor for measurement of $\mathrm{Cd}^{2+}$; concentration in aqueous solution based on reflective Mach-Zehnder interference with temperature calibration. Opt. Exp. 2019, 22, 32621-32629. [CrossRef] [PubMed]

6. Almeida, M.I.G.S.; Cattrall, R.W.; Kolev, S.D. Polymer inclusion membranes (PIMs) in chemical analysis-A review. Anal. Chim. Acta 2017, 987, 1-14. [CrossRef]

7. Kolev, S.D.; Almeida, M.I.G.S.; Cattrall, R.W. Polymer Inclusion Membranes: Smart materials for sensing and separation. In Handbook of Smart Materials in Analytical Chemistry, 1st ed.; de La Guardia, M., Esteve-Turrillas, F.A., Eds.; John Wiley \& Sons: Chichester, UK, 2019; Volume 1, pp. 439-461.

8. Suah, F.B.M. Preparation and characterization of a novel Co(II) optode based on polymer inclusion membrane. Anal. Chem. Res. 2017, 12, 40-46. [CrossRef]

9. Wang, D.; Liu, J.; Chen, J.; Liu, Q.; Zeng, H. New insights into the interfacial behavior and swelling of polymer inclusion membrane (PIM) during Zn (II) extraction process. Chem. Eng. Sci. 2020, 220, 115620. [CrossRef]

10. Qiu, X.; Hu, H.; Hu, F.; Tang, J.; Yang, C.; Zhou, Y.; Lin, X.; Hu, J. Simultaneous recovery of copper(II) from two different feed solutions based on a three-compartment module with selective polymer inclusion membranes. Hydrometallurgy 2019, 188, 64-72. [CrossRef]

11. Elias, G.; Díez, S.; Fontàs, C. System for mercury preconcentration in natural waters based on a polymer inclusion membrane incorporating an ionic liquid. J. Hazard. Mater. 2019, 371, 316-322. [CrossRef]

12. Anticó, E.; Fontàs, C.; Vera, R.; Mostazo, G.; Salvadó, V.; Guasch, H. A novel Cyphos IL 104-based polymer inclusion membrane (PIM) probe to mimic biofilm zinc accumulation. Sci. Total Environ. 2020, 715, 136938. [CrossRef] [PubMed]

13. González-Albarrán, R.; de Gyves, J.; de San Miguel, E.R. Influence of some physicochemical parameters on the passive sampling of copper (II) from aqueous medium using a polymer inclusion membrane device. Environ. Pollut. 2020, 258, 113474. [CrossRef] [PubMed]

14. Almeida, M.I.G.S.; Cattrall, R.W.; Kolev, S.D. Recent trends in extraction and transport of metal ions using polymer inclusion membranes (PIMs). J. Membr. Sci. 2012, 415-416, 9-23. [CrossRef]

15. Carner, C.A.; Croft, C.F.; Kolev, S.D.; Almeida, M.I.G.S. Green solvents for the fabrication of polymer inclusion membranes (PIMs). Sep. Purif. Technol. 2020, 239, 116486. [CrossRef]

16. Ngarisan, N.I.; Ngah, C.W.Z.C.W.; Ahmad, M.; Kuswandi, B. Optimization of polymer inclusion membranes (PIMs) preparation for immobilization of Chrome Azurol S for optical sensing of aluminum(III). Sens. Actuators B-Chem. 2014, 203, 465-470. [CrossRef]

17. Maiphetlho, K.; Chimuka, L.; Tutu, H.; Richards, H. Technical design and optimization of polymer inclusion membranes (PIMs) for sample pre-treatment and passive sampling-A review. Sci. Total Environ. 2021, 799, 149483. [CrossRef]

18. Rezaei, B.; Hadadzadeh, H.; Azimi, A. Fabrication of an optical sensor based on the immobilization of Qsal on the plasticized PVC membrane for the determination of copper (II). J. Anal. Chem. 2012, 67, 687-693. [CrossRef]

19. Ertekin, K.; Oter, O.; Ture, M.; Denizalti, S.; Cetinkaya, E. A long wavelength excitable fluorophore; chloro phenyl imino propenyl aniline (CPIPA) for selective sensing of Hg (II). J. Fluoresc. 2010, 20, 533-540. [CrossRef]

20. Scindia, Y.M.; Pandey, A.K.; Reddy, A.V.R.; Manohar, S.B. Chemically selective membrane optode for Cr(VI) determination in aqueous samples. Anal. Chim. Acta 2004, 515, 311-321. [CrossRef]

21. Casanueva-Marenco, M.J.; Díaz-de-Alba, M.; Herrera-Armario, A.; Galindo-Riaño, M.D.; Granado-Castro, M.D. Design and optimization of a single-use optical sensor based on a polymer inclusion membrane for zinc determination in drinks, food supplement and foot health care products. Mater. Sci. Eng. C-Mater. Biol. Appl. 2020, 110, 110680. [CrossRef]

22. Meng, X.; Jiang, X.; Long, Y.; Chen, J.; Wang, L.; Zhang, Y. Optical sensing membrane for determination of trace cadmium(II), zinc(II) and copper(II) based on immobilization of 1-(2-pyridylazo)-2-naphthol on polymer inclusion membrane. Microchem. J. 2021, 162, 105767. [CrossRef]

23. Coldur, M.; Oguzlar, S.; Ongun, M.Z.; Oter, O.; Yildirim, S. Usage of thiocyanate-based ionic liquid as new optical sensor reagent: Absorption and emission based selective determination of Fe (III) ions. Spectrochim. Acta Part A Mol. Biomol. Spectrosc. 2020, 224, 117385. [CrossRef]

24. Suah, F.B.M.; Ahmad, M.; Heng, L.Y. Highly sensitive fluorescence optode for aluminium(III) based on non-plasticized polymer inclusion membrane. Sens. Actuators B-Chem. 2014, 201, 490-495. [CrossRef]

25. Suah, F.B.M.; Ahmad, M. Preparation and characterization of polymer inclusion membrane based optode for determination of $\mathrm{Al}^{3+}$ ion. Anal. Chim. Acta 2017, 951, 133-139. [CrossRef]

26. Sharifi, H.; Tashkhourian, J.; Hemmateenejad, B. A 3D origami paper-based analytical device combined with PVC membrane for colorimetric assay of heavy metal ions: Application to determination of $\mathrm{Cu}(\mathrm{II})$ in water samples. Anal. Chim. Acta 2020, 1126, 114-123. [CrossRef] [PubMed]

27. Phichi, M.; Imyim, A.; Tuntulani, T.; Aeungmaitrepirom, W. Paper-based cation-selective optode sensor containing benzothiazole caliz [4]arene for dual colorimetric $\mathrm{Ag}^{+}$and $\mathrm{Hg}^{2+}$ detection. Anal. Chim. Acta 2020, 1104, 147-155. [CrossRef]

28. Marczenko, Z.; Balcerzak, M. Spectrophotometric reagents. In Separation, Preconcentration and Spectrophotometry in Inorganic Analysis, 1st ed.; Elsevier: Amsterdam, The Netherland, 2000; pp. 53-73.

29. Edelstein, M.; Ben-Hur, M. Heavy metals and metalloids: Sources, risks and strategies to reduce their accumulation in horticultural crops. Sci. Hortic. 2018, 234, 431-444. [CrossRef] 
30. Volesky, B. Detoxification of metal-bearing effluents: Biosorption for the next century. Hydrometallurgy 2001, 59, $2003-2216$. [CrossRef]

31. Langmuir, D.; Chrostowski, P.; Chaney, R.; Vigneault, B. Issue paper on the environmental chemistry of metals. In US EPA Archive Document; Environmental Protection Agency Risk Assessment Forum: Washington, DC, USA, 2003.

32. Yuan, Z.; Luo, T.; Liu, X.; Hua, H.; Zhuang, Y.; Zhang, X.; Zhang, L.; Zhang, Y.; Xu, W.; Ren, J. Tracing anthropogenic cadmium emissions: From sources to pollution. Sci. Total Environ. 2019, 676, 87-96. [CrossRef]

33. McDonald, S.; Cresswell, T.; Hassell, K. Bioaccumulation kinetics of cadmium and zinc in the freshwater decapod crustacean Paratya australiensis following multiple pulse exposures. Sci. Total Environ. 2020, 720, 137609. [CrossRef]

34. Figueira, E.; Lima, A.; Branco, D.; Quintino, V.; Rodrigues, A.M.; Freitas, R. Health concerns of consuming cockles (Cerastoderma edule L.) from a low contaminated coastal system. Environ. Int. 2011, 37, 956-972. [CrossRef] [PubMed]

35. REGLAMENTO (UE) No 488/2014 DE LA COMISIÓN de 12 de mayo de 2014 que Modifica el Reglamento (CE) no 1881/2006 por lo que Respecta al Contenido Máximo de Cadmio en los Productos Alimenticios. Available online: https://www.boe.es / doue/2014/138/L00075-00079.pdf (accessed on 1 November 2021).

36. Choi, W.J.; Kang, S.K.; Ham, S.; Chung, W.; Kim, A.J.; Kang, M. Chronic cadmium intoxication and renal injury among workers of a small-scale silver soldering company. Saf. Health Work 2020, 11, 235-240. [CrossRef] [PubMed]

37. Faroon, O.; Ashizawa, A.; Wright, S.; Tucker, P.; Jenkins, K.; Ingerman, L.; Rudisill, C. Toxicological Profile for Cadmium; Agency for Toxic Substances and Disease Registry (US): Washington, DC, USA, 2012. [PubMed]

38. Gardener, H.; Bowen, J.; Callan, S.P. Lead and cadmium contamination in a large sample of United States infant formulas and baby foods. Sci. Total Environ. 2019, 651, 822-827. [CrossRef] [PubMed]

39. Zvěřina, O.; Kuta, J.; Coufalík, P.; Kosečková, P.; Komárek, J. Simultaneous determination of cadmium and iron in different kinds of cereal flakes using high-resolution continuum source atomic absorption spectrometry. Food Chem. 2019, 298, 125084. [CrossRef]

40. O'Mara, K.; Adams, M.; Burford, M.A.; Fry, B.; Cresswell, T. Uptake and accumulation of cadmium, manganese and zinc by fisheries species: Trophic differences in sensitivity to environmental metal accumulation. Sci. Total Environ. 2019, 690, 867-877. [CrossRef]

41. Jain, R.B. Concentrations of cadmium, lead, and mercury in blood among US cigarettes, cigars, electronic cigarettes, and dual cigarette-e-cigarette users. Environ. Pollut. 2019, 251, 970-974. [CrossRef]

42. Baloch, S.; Kazi, T.G.; Baig, J.A.; Afridi, H.I.; Arain, M.B. Occupational exposure of lead and cadmium on adolescent and adult workers of battery recycling and welding workshops: Adverse impact on health. Sci. Total Environ. 2020, 720, 137549. [CrossRef]

43. Turner, A. Cadmium pigments in consumer products and their health risks. Sci. Total Environ. 2019, 657, 1409-1418. [CrossRef]

44. Jha, R.; Dhanunjaya, R.; Meshram, A.; Verma, H.R.; Singh, K.K. Potential of polymer inclusion membrane process for selective recovery of metal values from waste printed circuit boards: A review. J. Clean Prod. 2020, 265, 121621. [CrossRef]

45. Motsoane, N.; Maiphetlho, K.; Ncube, S.; Richards, H.; Kotze, I.; Tutu, H.; Cukrowska, E.; Chimuka, L. Technical development and optimisation of a passive sampler based on polymer inclusion membrane for uptake of copper, nickel, cobalt and cadmium in surface waters. Environ. Technol. Innov. 2020, 19, 100939. [CrossRef]

46. Annane, K.; Sahmoune, A.; Montels, P.; Tingry, S. Polymer inclusion membrane extraction of cadmium(II) with Aliquat 336 in micro-channel cell. Chem. Eng. Res. Des. 2015, 94, 605-610. [CrossRef]

47. Sanchez-Pedreño, C.; García, M.S.; Ortuño, J.A.; Albero, M.I.; Expósito, R. Kinetic methods for the determination of cadmium(II) based on a flow-through bulk optode. Talanta 2002, 56, 481-489. [CrossRef]

48. Tharakeswar, Y.; Kalyan, Y.; Gangadhar, B.; Dumar, K.S.; Naidu, G.R. Optical chemical sensor for screening cadmium(II) in natural waters. J. Sens. Technol. 2012, 2, 68-74. [CrossRef]

49. García-Vargas, M.; Bautista, J.M.; De Toro, P. Analytical possibilities of pyridine-2-acetaldehyde benzoylhydrazone as a chromogenic reagent. Microchem. J. 1981, 26, 557-568. [CrossRef]

50. Zidan, A.S.A. Mixed ligand complexes of nickel (II) dialkyldithiophosphates with 2-acetylpyridine semicarbazone and 2acetylpyridine benzoylhydrazone. Phosphorus Sulfur Silicon Relat. Elem. 2003, 178, 567-582. [CrossRef]

51. Granado-Castro, M.D.; Galindo-Riaño, M.D.; Domínguez-Lledó, F.C.; Díaz-López, C.; García-Vargas, M. Study of the kinetics of the transport of $\mathrm{Cu}(\mathrm{II}), \mathrm{Cd}(\mathrm{II})$ and $\mathrm{Ni}(\mathrm{II})$ ions through a liquid membrane. Anal. Bioanal. Chem. 2008, 391, 779-788. [CrossRef] 